\title{
AUDIO DESCRIPTION AND THE TRANSLATION OF FILM LANGUAGE INTO WORDS
}

\author{
Floriane Bardini ${ }^{1^{*}}$ \\ ${ }^{1}$ University of Vic - Central University of Catalonia, Barcelona, Espanha
}

\begin{abstract}
:
This paper approaches audio description (AD) from a Translation Studies point of view. The two first parts are of theoretical interest: $A D$ is defined as a part of the audiovisual text and as a form of intersemiotic translation. Once this is set up, the paper concentrates on the concept of translation techniques and adapts them to audio description to provide scholars and students with a functional classification of AD techniques (ADT), which can be used for descriptive studies of audio descriptions as well as in training, and is based on a functional classification of translation techniques. The paper ends with detailed examples from a comparative study of several audio descriptions of the film Slumdog Millionaire (2008) using ADTs to illustrate the benefits of the established taxonomy.

Keywords: Audiovisual Translation; Audiovisual Accessibility; Audio Description; Translation Techniques; Functionalism
\end{abstract}

\footnotetext{
"Translator and doctoral researcher. She has worked as a French teacher in Germany and Catalonia before completing her Master in Specialised Translation at the University of Vic - Central University of Catalonia, where she is now conducting research in the field of audiovisual translation and media accessibility. Her doctoral dissertation focuses on film language audio description and user experience. E-mail: floriane.bardini@ uvic.cat ; florianebardini@yandex.com. ORCID : 0000-0001-5116-6631
} 


\section{Introduction}

Audio description (AD) is a mode of media accessibility that turns visual elements into a verbal text to provide access for the blind and partially sighted audiences. Research into media accessibility has experimented a boost as the efforts to work towards inclusive societies have increased, and political steps, such as the adoption of the UN Convention on the Rights of Persons with Disabilities ${ }^{1}$, have been taken. Investigation in the field is mainly carried out in Translation faculties as, according to Díaz Cintas (2005, p. 4) "whether the hurdle is a language or a sensory barrier, the aim of the translation process is the same: to facilitate the access to an otherwise hermetic source of information and entertainment." Over the last decade, $\mathrm{AD}$ has consolidated its position as a translational activity: in the ADLAB Pro project (2016), which aims at creating didactic materials for audio describers, these professionals are defined as "audiovisual translator[s] charged with producing verbal descriptions for the blind community." Therefore, in this paper, we approach audio description from a Translation Studies point of view.

The beginning of the paper sets our theoretical frame: $\mathrm{AD}$ is defined as a part of the audiovisual text and as a form of intersemiotic translation. Once this is set up, we concentrate on the concept of translation techniques and adapt it to AD. Translation techniques have been used successfully by several scholars as an analysis tool for AD descriptive studies (e.g. Matamala \& Rami, 2009; Mazur, 2014) but the field of AD still lacks a classification of its own. As a response to this observation, the aim of this paper is to offer such a classification for AD scholars and students, and we present a taxonomy of audio description techniques (ADT) based on Molina and Hurtado's (2002) functional approach to translation techniques. Finally, we give two detailed examples from a comparative study of describers' approach to cinematic language in Slumdog Millionaire (2008) using ADTs, to demonstrate the purpose of the taxonomy we provide. ${ }^{2}$

\section{Audio description as part of the audiovisual text}

The Spanish accessibility standard UNE 153020:2005 (AENOR, 2005) defines audio description as follows:

Audio description is an assistive service consisting of a set of techniques and abilities, whose main objective is to compensate for the lack of perception of the visual component in any audiovisual message, by providing suitable sound information which translates or explains, in such a way that the visually impaired perceive the message as a harmonious work which is as similar as possible to that which is perceived by the sighted (AENOR, 2005, p. 4, translated by Utray et al., 2009, p. 249).

This definition is fundamental in that it both adapts to any kind of visual message and extends the function of media accessibility to experience - and not only information - when it mentions the way the message should be 
perceived. That being said, as a starting point, this article uses a simplified definition, coined by Orero (2008, p. 179): "Audio description (AD) is the name given to the technique which makes audiovisual texts accessible for those who have no access to the visual channel." The audiovisual texts we will focus on are feature films and the objects of our study are both the audiovisual texts and the corresponding $\mathrm{AD}$ scripts, although it is important to point out that other components of the $\mathrm{AD}$ process (e.g. voicing) also have an influence on the quality of the audio described product.

Zabalbeascoa (2008,p.24) defines the audiovisual screen text as "a combination of verbal, non-verbal, audio and visual elements to the same degree of importance" where "the various elements are meant to be essentially complementary and as such may be regarded as inseparable for a fully satisfactory communication event." According to this definition, if $\mathrm{AD}$ is to act as an audio substitute for the visual components, it has to be carried out in a fashion that ensures its interaction with the existing audio in order to maintain the original complementarity of the channels. Furthermore, as a substitute for the visual, AD must deliver the verbal and non-verbal information entailed in the visual part of a film. According to Zabalbeascoa, visual, audio, verbal and non-verbal are all equally important for generating the audiovisual message. Yet their quantitative presence and balance varies. If we take the specific example of a talking motion picture, the audio part most often contains a great number of non-verbal elements in the form of music and sound effects, and a nearly as significant verbal component in form of dialogue, song lyrics, a narrator, etc. At a visual level, on the contrary, there is a clear prevalence of the non-verbal mode: images are at the core of the product and they are the main material the describer must deal with. There are some verbal elements shown on screen that also need to be audio described, i.e. written text, be it diegetic (text of a sign, etc.) or extradiegetic (credits, subtitles) (Ofcom, 2000, p. 22-23; AENOR, 2005, p. 8), but this information usually represents a very small part of an audio description in comparison with the verbalized nonverbal components. Hence, audio describing a film implies that a two-channel product becomes mono-channel and, in consequence, non-verbal elements become verbal, as images are turned into words. Therefore, AD mainly deals with the transposition of non-verbal language into the verbal system, i.e. with turning what is shown on screen and how it is shown into a verbal text.

\section{Audio description as intersemiotic translation}

As we have just seen, $\mathrm{AD}$ consists of a shift from one semiotic system (the non-verbal) to another (the verbal). This is a form of "intersemiotic translation" (or "transmutation"), which was defined by Roman Jakobson as "an interpretation of verbal signs by means of signs of nonverbal sign systems" (Jakobson, 1959). In fact, $\mathrm{AD}$ is just the opposite of Jakobson's transmutation as it involves the verbal interpretation of non-verbal signs. As Díaz Cintas (2007a, p. 16, my translation) remarks, his "classification needs to be revised to include other dimensions, like 
the audio and the visual in our case, but the essence lies in the proposal of the Russian theorist," and $\mathrm{AD}$ has been researched and taught mainly within the scope of Translation Studies as a form of audiovisual translation (Díaz Cintas, 2007a; Braun, 2008).

If translation theory leads us to consider $\mathrm{AD}$ a form of translation, this approach also appears to be pertinent at a practical level. Díaz Cintas (2007b, p. 52-57) has reviewed and organized the competences that audio describers need to develop; his categories and their components mostly match those of the translation competence model developed by the PACTE research group (PACTE, 2011, p. 319-320):

- "Linguistic competences" comprehend an extensive knowledge of the mother tongue, linguistic sensibility and knowledge of English, and are similar to PACTE's "linguistic sub-competence";

- "Thematic and content competences" encompass knowledge of disability in general and visual disability in particular, knowledge of filmic language and semiotics, knowledge of the work market, etc. and match PACTE's categories "translation knowledge sub-competence" and "extra linguistic sub-competence";

- "Technological and applied competences" embrace computing skills, documentation skills, vocal skills etc., and correspond to PACTE's "instrumental sub-competence";

- "General and personal attitude" includes, among others, quick thinking, organization skills and analytic and synthetic ability, which also appear in PACTE’s "psycho-physiologic components."

It pays to indicate that PACTE also identifies a "strategic sub-competence" which does not appear as such in Díaz Cintas' exhaustive skills review, as his aim is not to present a theoretical model of audio description competence but to give practical advice for quality training in audiovisual accessibility. The "strategic sub-competence" is a more global competence linked to the translator's capacity to transfer a message from one language into another and corresponds to audio describers' ability to apply their skills to satisfactorily render an audiovisual message into words. To approach this strategic ability or "transference skill" (González Davies, 2004, p. 131-132), Pym’s (2003) “minimalist approach" to translation competence offers an interesting ground. Pym (2003, p. 489) defines translation competence as:

- The ability to generate a series of more than one viable target text $\left(\mathrm{TT}_{1}, \mathrm{TT}_{2}\right.$ $\ldots \mathrm{TT}_{\mathrm{N}}$ ) for a pertinent source text (ST); 
- The ability to select only one viable TT from this series, quickly and with justified confidence.

This definition gets to the core of translation competence without excluding all necessary aptitudes and abilities involved in a translational activity - and it applies perfectly to audio description as well. A describer should be able to decide what to describe and how to describe it, which implies the existence of multiple potential ADs, the most suitable of which then has to be selected consciously. With growing experience or under time pressure (e.g. in live AD), the process may seem to take place intuitively or automatically, in the same way as solving a translation problem sometimes does (Pym, 2003, p. 489; González Davies \& Scott-Tennent, 2005, p. 161-162). Concurring with Pym's definition, the study presented in section 5 of this article shows that different approaches to describing the same film or film fragment coexist and can be justified (e.g. with reference to existing guidelines), with the result that more than one viable $\mathrm{AD}$ of the same audiovisual text can be generated.

\section{From translation techniques to audio description techniques}

Translation techniques can contribute to generating several viable (and intrinsically different) target texts, in that they allow translators to shape their translations at a segment level, which may have an impact at a text level - one well-known example of this being the use of borrowing to produce a foreignizing effect (Molina \& Hurtado, 2002, p. 508). In audiovisual translation, translation techniques have been used by Martí Ferriol (2006) in his research on translation method for dubbing and subtitling, as well as by Pedersen (2011) in his work on subtitling norms on television. In the more restricted field of $\mathrm{AD}$ research, translation techniques have been used by Matamala and Rami (2009) in an analysis of the $\mathrm{AD}$ of cultural elements in the German and Spanish ADs of the film Goodbye Lenin (2003, directed by W. Becker), by Mazur (2014) in her study of the $\mathrm{AD}$ of gestures and facial expressions, by Szarkowska and Jankowska (2015) in their research on the AD of foreign culture elements in the Polish context, and by Sanz-Moreno (2017) in her studies of the AD of sex and of the use of foreign words in AD (2018). This recurrent interest of scholars in the field for translation techniques (which Szarkowska and Jankowska (2015) and Mazur (2014) call "strategies") demonstrates the need for a translation techniques model for AD. Following Matamala and Rami (2009), we base our proposal on Molina and Hurtado's (2002) "dynamic and functionalist approach" and adapt their translation techniques taxonomy to $\mathrm{AD}$.

Translation techniques were introduced by Jean-Paul Vinay and Jean Darbelnet in their work Stylistique comparée du français et de l'anglais. Méthode de Traduction (Vinay \& Darbelnet, 1958), where they presented their 21 "translation technical procedures" - "the initial proposal" according to Zabalbeascoa (2000, p. 117). Since then, the subject has been tackled by many scholars and, as a 
result, many parallel proposals co-exist and the terms strategies, procedures, methods and techniques have been confused (Muñoz, 2000; Molina \& Hurtado, 2002; Gil Bardají, 2009). Molina and Hurtado’s approach appears very valuable in this sense, as they merge the proposals of different scholars into one model and clear the terminological confusion by dismissing the term "procedure" and defining "strategies" as ways of solving problems, "methods" as options that affect the whole text, and "techniques" as options that affect micro units of the text (Molina \& Hurtado, 2002, p. 509). Furthermore, their functional approach bans prescriptivism and implies an analysis of the use of translation techniques, which are not assigned any vices or virtues: they must be evaluated in their context and considering what purpose they are to fulfil. Besides, Molina and Hurtado (2002, p. 509) include "procedures that are characteristic of the translation of texts and not those related to the comparison of languages", so that they are perfectly applicable to intersemiotic translation.

According to Molina and Hurtado (2002, p. 509), "a technique is the result of a choice made by a translator, its validity will depend on various questions related to the context, the purpose of the translation, audience expectations, etc., and translation techniques can be defined as "procedures to analyse and classify how translation equivalence works." According to the two scholars, translation techniques have five basic characteristics (Molina \& Hurtado, 2002, p. 509):

1) They affect the result of the translation

2) They are classified by comparison with the original

3) They affect micro-units of text

4) They are by nature discursive and contextual

5) They are functional

On this base, this paper suggests the following definition for audio description techniques:

Audio description techniques (ADT) are options available to audio describers to render the audiovisual message into the verbal system when audio describing a fragment of an audiovisual text. The main characteristics of ADT are that (1) they are functional: each technique should be evaluated in its context, taking into account the constraints and aims at stake when writing the AD script; (2) ADT are combinable: a describer can use more than one technique at once to describe a fragment, and the use of a particular technique in a particular situation may imply the use of another one; and (3) ADT affect the AD script at a micro-level, which in turn may affect the AD style at a macro-level.

Drawing from Molina and Hurtado's work (2002, p. 508-511), we have identified fourteen $\mathrm{AD}$ techniques, which are listed and defined below. Each corresponds to one of Molina and Hurtado's translation techniques. Their "borrowing", "linguistic amplification", "linguistic reduction" and "transposition" do not have an equivalent in our system as they are specific to verbal language, but we could adapt their definitions of all other techniques to $\mathrm{AD}$ and, unless indicated otherwise, we have kept their terminology. We believe that this 
taxonomy can easily be adapted to other forms of visual art but, as for now, it is based on research into film audio description. Each technique is illustrated by examples taken out of a comparison of the British, German and Spanish ADs of the film Slumdog Millionaire (2008, directed by D. Boyle and L. Tandan; see synopsis in endnote ${ }^{3}$ ). In an effort to unify concepts and terminologies, we also comment on how other scholars have used AD techniques in their work.

\section{Amplification}

Amplification consists in extending the information provided in the $\mathrm{AD}$ by introducing extra details or by combining several techniques. Amplification includes a range of subcategories such as addition, explicitation or explication.

Example (1) [TCR ${ }^{4}$ 18:26:09] The English AD “[...] a young boy dressed as the Hindu God, Rama. He is covered in blue paint, with his hair bound up on his head" is an explication of what is represented by the painted little boy.

Explication and explicitation are a combination of particularisation and iconic description (see below) and appear in the work of several researchers under the label "naming and describing", e.g. in Mazur (2015) or Szarkowska and Jankowska (2015). These techniques are commonly used in the AD of foreign films: Szarkowska and Jankowska give the example of an explicitation in the Polish AD of Midnight in Paris (2011, directed by W. Allen), where the Parisian Grand Palais building's "name itself was preceded by the term gmach ('edifice'), which not only explained to the viewers that the name refers to a building, but also gave them an indication of its great size" (Szarkowska \& Jankowska, 2015, p. 252). Mazur (2014) uses the term "explicitation" as well in her study of the AD of facial expressions and gestures, but the concept lying behind the word is different in her work and corresponds to substitution in this classification (see below).

A special form of amplification is audio introduction, an introductory note delivered prior to the representation of a live event or the beginning of a film, in order to "engage the listener's attention, whet their appetite and, most importantly, enable them to appreciate the film's inherent cinematic qualities" (Fryer \& Romero-Fresco, 2014).

\section{Reduction}

Reduction is a very brief $\mathrm{AD}$ of an element or a fragment. Bearing in mind that $\mathrm{AD}$ has to fit in the dialogue gaps and not interfere with important music or sound effects - and is therefore often subjected to extreme time constraints every $\mathrm{AD}$ is bound to be a reduction of the audiovisual content. For this reason, reduction is relevant for analysis when it is used in fragments where enough time is provided to describe more, where specific elements are omitted, etc. 
Example (2) [TCR 00:08:32] Jamal and Salim are at school. There is a quick close-up on the book The Three Musketeers by Alexandre Dumas. Time constraints make it impossible to include the information in the $\mathrm{AD}$ at that moment, so that it is omitted in the English and German ADs. Yet, the Three Musketeers is a recurrent theme in the film, so it would have been interesting to have the information somehow (see example 4).

Omission is the most extreme form of reduction and a subcategory of its own, which also appears in research by Matamala and Rami (2009), Mazur (2014) and Szarkowska and Jankowska (2015).

Euphemism, which may appear for example in the description of sex scenes (Fryer, 2016, p. 145; Sanz-Moreno, 2017, p. 52) is another form of reduction.

\section{Generalisation}

Generalisation is the use of a general or superficial description where the audiovisual content and the available silent gap would allow for a more detailed or precise description.

Example (3) [TCR 00:07:07] A man is collecting waste from a river in the Mumbai slum and the Spanish AD says "Todo está rodeado de basura y de inmundicias por todos lados." [There is waste and filth all over the place.]

Szarkowska and Jankowska (2015) underline the usefulness of this technique "in the $\mathrm{AD}$ for foreign films, particularly when the foreign culture-bound element does not have its equivalent in the target language." This is the case in Fill the Void (2012, directed by R. Buhrstein), where a traditional keffyeh is described as "a turban looking headscarf" (Szarkowska \& Jankowska, 2015, p. 8).

\section{Particularisation}

Particularisation is the use of a precise term for a specific element of the original audiovisual text.

Example (4) [TCR 00:08:55] "El maestro les golpea en la cabeza con el libro de Los tres Mosqueteros." [The teacher hits them on the head with the book The Three Musketeers.] In this case, the particularisation is a way of insisting on the presence of the book The Three Musketeers and serves as a compensation (see below) because, a moment after, a close-up on the book, which has its importance later in the story, cannot be described due to time restrictions.

Particularisation can be a way of pointing at a specific element, as is the case with the technique "name insertion" identified by Szarkowska and Jankowska (2015), which consists in inserting the name of a person before they speak to 
reinforce the information conveyed by the soundtrack and avoid confusions. The technique "naming" as used by Walczak and Figiel (2013), which consists in using the name of a culture specific item not familiar to the target audience, is also a form of particularisation. So is "name", the technique Mazur (2015) refers to when one states the name of a character instead of describing it, be it real like "Virginia Woolf" or imaginary like "a Hobbit."

\section{Compensation}

Compensation is the description of elements before or after they occur instead of simultaneously. It may be a deliberate choice of the describer but, more often than not, this technique comes into play when important elements cannot be described at the same time as they occur due to time restrictions (Ofcom, 2000, p. 15; Igareda, 2011, p. 235).

Example (5) [TCR 00:16:58] When Jamal's mother is clubbed on the head during a riot and falls into a pool, the German AD says "Sie stürzt leblos ins Wasser" [She falls dead in the water] although we will know for sure that the mother is dead only at the end of the sequence, when there is a short shot of her, floating face down in the pool.

\section{Substitution}

Substitution is the interpretation in the AD of extra-linguistic elements displayed in the film, like gestures or facial expressions. Substitution is a special form of cognitive description (see below).

Example (6) [TCR 01:25:08] "He looks puzzled as he returns to the studio floor." Here, the facial expression of the character is not described but interpreted into "puzzled".

Example (7) [TCR 01:40:59] When the director of the show signals by a gesture that they are about to hang up the call to Jamal's joker, the Spanish audio describer interprets this gesture and says "Desde realización le indican al presentador que van a colgar la llamada." [From the director's booth, they inform the host that they are going to hang up the call.]

Mazur uses the terms "explicitation" (Mazur, 2014) and "name the gesture" (Mazur, 2015) to refer to substitution.

\section{Adaptation}

Adaptation is the substitution of a cultural element of the original audiovisual text by a cultural element of the target culture in the $\mathrm{AD}$. 
Example (8) The chai-wallah Jamal is described as a chico de los cafés ('coffee guy') instead of chico del te ('tea guy') in the audio introduction to the Spanish audio described version of Slumdog Millionaire.

To refer to this technique, Szarkowska and Jankowska (2015) use the term "substitution" coined by Pedersen (2011). Even though the cultural item of the target text does substitute the cultural element of the source text, we prefer to stick to Molina and Hurtado's terminology here, for two reasons. First, because adaptation (or cultural adaptation) is a procedure familiar to translation professionals and scholars. Second, because Molina and Hurtado (2002, p. 511) use the term "substitution" for the translation of extra-linguistic elements, which is particularly relevant in $\mathrm{AD}$ (see above).

\section{Iconic description}

Iconic description corresponds to Molina and Hurtados "literal translation" (Molina \& Hurtado, 2002, p. 510). It is an AD of the audiovisual source text at an iconic level, i.e. a denotative description of the images that appear on-screen. It is the closest to the "objective" description that official $\mathrm{AD}$ guidelines usually strive for (Dosch \& Benecke, 2004, p. 9; AENOR, 2005, p. 8; Morisset \& Gonant, 2008, p. 5).

Example (9) [TCR 00:13:19] "Salim enters the projectionist's booth. He shows him Jamal's autographed photo of Amitabh."

Iconic descriptions can be more or less detailed according to the time slot available to describe and to the relevance of the elements to be described.

\section{Integral iconic description}

Integral iconic description corresponds to Molina and Hurtado's "description" (Molina \& Hurtado, 2002, p. 510). It is the description of elements belonging to general knowledge instead of using their common name, or the description of body language instead of interpreting it.

Example (10) [TCR 00:39:31] In the German AD, the Taj Mahal is not referred to as such but as "ein weißes palastartiges Gebäude" [a white palatial building].

Example (11) [TCR 01:40:59] The director of the show indicates that they are about to hang up the call to Jamal's joker by a gesture that is described in the English AD: "The host looks at the director who shakes his head and makes a cutting motion against his throat." 
Another example of integral iconic description (which Mazur (2015) calls "describe") is that of the description of a hobbit as a "short human-like creature with slightly pointed ears and large fur-covered feet" (Mazur, 2015). The technique can be combined with a particularisation by stating that the creature is a hobbit, thus building an amplification and completing the information offered to the audience. Integral iconic description is particularly useful in films with elements of foreign culture to ease the construction of mental pictures of these elements by the blind and partially sighted audience (Sanz-Moreno, 2018, p. 56).

\section{Technical description}

Technical description corresponds to Molina and Hurtado's "calque" (Molina \& Hurtado, 2002, p. 510). It is the use of technical terminology related to the support of the audio described material. In the case of film, it corresponds to the use of cinematic terminology such as "aerial view" at [TCR 00:47:58] or "images move backwards" at [TCR 01:47:36] in the English AD version of Slumdog Millionaire. Perego (2015) calls this technique "name the technique". AD guidelines (Ofcom, 2000, p. 6; Morisset \& Gonant, 2008, p.3) recommend not to overuse technical description. Fryer and Freeman (2013) challenged this recommendation using the technique repeatedly in a "cinematic $\mathrm{AD}^{\text {" that they }}$ successfully tested with end users.

\section{Cognitive description}

Cognitive description corresponds to Molina and Hurtado's "established equivalent" (Molina \& Hurtado, 2002, p. 510). It is an $\mathrm{AD}$ of the audiovisual source text that is the result of an interpretation of an image or a film technique, in conformity with the alleged purposes of the audiovisual text.

Example (12) [TCR 00:03:48] The visual interaction between Jamal and the police inspector is shown by an alternation of shots of Jamal's face as he looks to the camera, and of the Inspector's face, as he also looks to the camera, and is described as follows: "Los dos se miran fijamente." [The two stare at each other.]

Example (13) [TCR 00:51:42] This example is a transition between two shots by a "match on movement" (Aumont et al., 1992, p. 56): Jamal runs out of the subway through smoke in the opposite direction from the camera, then in the next frame, the smoke of a street dissolves and he appears walking towards the camera with his brother. The English AD reads "A worker starts to fumigate the subway. Jamal disappears, running through the smoke. He emerges with Salim through exhaust fumes on Pila Street at night". The verb "emerges" links the two scenes by transmitting the idea of a movement from one place to another through the smoke, which is not an actual movement but the interpretation of a cinematic effect. 
The film technique at work in example (12) is known as the shot/reverse shot technique (Aumont et al., 1992, p. 56), which is automatically interpreted by viewers as an exchange of looks. In this case, the meaning of the cinematic technique has become conventional, and there is no doubt it should be interpreted and translated into words in the AD. Hence, the correspondence with Molina and Hurtado's established equivalent. However, according to Metz (1959, p. 59, my translation), "we do not understand a film because of its syntax, we understand the syntax of a film because we understood the film." In other words, cinematic language may have its conventions, but it also gives a director the licence to create new expressions, which will be valid and understood if interpreted in their context, and for which an equivalent in the verbal language can be established and rendered in $\mathrm{AD}$ through a cognitive description, as in example (13). Perego (2015) refers to the cognitive description of film techniques as "describe the meaning of the technique".

Metaphor is a particular form of cognitive description, as it allows to render an effect and requires an interpretation of the visuals to create the corresponding image. It is used for example in scientific documentaries "to convey the shapes and movements of specific images shown on screen," as pointed out by Cámara and Espasa (2011, p. 420), for example when describing how "leaves unfold like fingers opening."

\section{Creative description}

Creative description corresponds to Molina and Hurtado's "discursive creation" (Molina \& Hurtado, 2002, p. 510). It is an AD of the audiovisual source text mostly at a connotative level, which focusses on delivering the global meaning of a film fragment, i.e. an $\mathrm{AD}$ that is the result of an interpretative reading of a fragment and tends neither to reproduce accurately the iconic contents of the picture nor to follow the exact order and duration of the shots as is usually requested by $\mathrm{AD}$ guidelines (Ofcom, 2000, p. 13; AENOR, 2005, p. 8).

Example (14) [TCR 00:42:02] "Pasan los meses. Los dos hermanos van creciendo mientras siguen haciendo de guías improvisados, y robando todo lo que pueden a los turistas. [...] Su escaso nivel de vida va mejorando." [Months pass. As the two brothers grow up, they still work as fake guides, stealing all they can from tourists. [...] Their low standard of living keeps improving.]

In this example, creative description is used in a sequence where several years are summed up in a few minutes, so that the fragment lends itself to a more narrative tone. 


\section{Modulation}

Modulation is a change of focus in the $\mathrm{AD}$ compared to the original audiovisual text.

Example (15) [TCR 00:36:31] "Salim stares at a pensive Jamal." Salim becomes the subject in the $\mathrm{AD}$ although he first appears blurry in the film, as the camera actually focusses on Jamal.

\section{Variation}

Variation is a deviation of standard language or neutral aural delivery in the AD.

Example (16) [TCR 01:10:14] When Jamal punches Salim in the face, the Spanish AD reads "Se acerca y le encaja un buen derechazo en la mandíbula." [He comes closer and wallops his brother in the jaw with the right fist.]

Variation may be used to achieve adequacy to the described work or to fit the atmosphere of a fragment. In some cases, it can be used recurrently, like in "auteur description", an AD style developed by Szarkowska (2013, p.383) "which incorporates the director's creative vision in the $\mathrm{AD}$ script through the use of a screenplay" or other materials. In her work, the evocative language of the $\mathrm{AD}$ of Volver (2006, directed by P. Almodóvar) clearly departs from guidelines' prescriptions but it does justice to the director's style. As far as voicing is concerned, Fryer (2016, p. 88-89) acknowledges that "neutral delivery has come to be recognised as 'the norm"' but she gives an example of variation in the $\mathrm{AD}$ of Borat (2006, directed by L. Charles) where "audio subtitles are read in a fake (and ludicrous) Kazakhstan accent" that fits very well with the satirical style of this unconstrained mockumentary.

Going through this taxonomy of $\mathrm{AD}$ techniques, we have seen that the ADT approach can cover a wide range of subjects (cultural references, taboos, emotions, etc.) and offers interesting insights into describer's decisions and how they affect the AD script. Nonetheless, in the examples taken from other research, we have seen some over-lapping in the terminology and concepts used by different scholars. Sometimes, several terms are used to refer to the same technique, and, at other times, the same term refers to different concepts. In our opinion, the benefits of Molina and Hurtado's (2002) classification, which clears terminological confusion and federates concepts that had emerged from half a century of research in Translation Studies, apply to AD as well, and we aim to offer a classification of ADT that may work with any subject of study and remain open to the addition of relevant sub-categories. The fourteen ADT are summed up in Chart 1. 
Chart 1 - AD Techniques

\begin{tabular}{|c|c|c|}
\hline $\begin{array}{l}\text { Audio Description } \\
\text { Technique }\end{array}$ & Definition & $\begin{array}{l}\text { Molina and Hurtado's (2002) } \\
\text { corresponding technique and definition }\end{array}$ \\
\hline Amplification & $\begin{array}{l}\text { AD that extends the } \\
\text { information provided in } \\
\text { the audiovisual text by } \\
\text { introducing extra details } \\
\text { or by combining several } \\
\text { techniques. }\end{array}$ & $\begin{array}{l}\text { Amplification } \\
\text { "To introduce details that are not } \\
\text { formulated in the ST." }\end{array}$ \\
\hline Reduction & $\begin{array}{l}\text { Very brief (or inexistent) AD } \\
\text { of an element or a fragment. }\end{array}$ & $\begin{array}{l}\text { Reduction } \\
\text { "To suppress a ST information item in the } \\
\text { TT." }\end{array}$ \\
\hline Generalisation & $\begin{array}{l}\text { The use of a general or } \\
\text { superficial description where } \\
\text { the audiovisual content and } \\
\text { the available silent gap would } \\
\text { allow for a more detailed or } \\
\text { precise description. }\end{array}$ & $\begin{array}{l}\text { Generalisation } \\
\text { "To use a more general or neutral term." }\end{array}$ \\
\hline Particularisation & $\begin{array}{l}\text { The use of a precise term to } \\
\text { describe a specific element of } \\
\text { the original audiovisual text. }\end{array}$ & $\begin{array}{l}\text { Particularisation } \\
\text { "To use a more precise or concrete term." }\end{array}$ \\
\hline Compensation & $\begin{array}{l}\text { The description of elements } \\
\text { before or after they occur } \\
\text { instead of simultaneously. }\end{array}$ & $\begin{array}{l}\text { Compensation } \\
\text { "To introduce a ST element of information } \\
\text { or stylistic effect in another place in the TT." }\end{array}$ \\
\hline Substitution & $\begin{array}{l}\text { The interpretation of extra- } \\
\text { linguistic elements like } \\
\text { gestures or facial expressions. }\end{array}$ & $\begin{array}{l}\text { Substitution } \\
\text { "To change linguistic elements for } \\
\text { paralinguistic elements (intonation, } \\
\text { gestures) or vice versa." }\end{array}$ \\
\hline Adaptation & $\begin{array}{l}\text { The substitution of a cultural } \\
\text { element of the original } \\
\text { audiovisual text by a cultural } \\
\text { element of the target culture } \\
\text { in the AD. }\end{array}$ & $\begin{array}{l}\text { Adaptation } \\
\text { "To replace a ST cultural element with one } \\
\text { from the target culture." }\end{array}$ \\
\hline Iconic Description & $\begin{array}{l}\text { Denotative AD of a fragment } \\
\text { of the audiovisual source text. }\end{array}$ & $\begin{array}{l}\text { Literal Translation } \\
\text { "To translate a word or an expression word } \\
\text { for word." }\end{array}$ \\
\hline $\begin{array}{l}\text { Integral Iconic } \\
\text { Description }\end{array}$ & $\begin{array}{l}\text { The description of elements } \\
\text { belonging to general } \\
\text { knowledge instead of using } \\
\text { their common name, or the } \\
\text { description of body language } \\
\text { instead of interpreting it. }\end{array}$ & $\begin{array}{l}\text { Description } \\
\text { "To replace a term or expression with a } \\
\text { description of its form or/and function." }\end{array}$ \\
\hline Technical Description & $\begin{array}{l}\text { The use of technical } \\
\text { terminology related to the } \\
\text { nature of the audio described } \\
\text { material (e.g. cinematic } \\
\text { terminology). }\end{array}$ & $\begin{array}{l}\text { Calque } \\
\text { "Literal translation of a foreign word or } \\
\text { phrase; it can be lexical or structural." }\end{array}$ \\
\hline Cognitive Description & $\begin{array}{l}\text { AD that interprets an image } \\
\text { or a technique (e.g. cinematic } \\
\text { or film technique) to render } \\
\text { its effect or meaning into } \\
\text { words. }\end{array}$ & $\begin{array}{l}\text { Established Equivalent } \\
\text { "To use a term or expression recognized } \\
\text { (by dictionaries or language in use) as an } \\
\text { equivalent in the TL." }\end{array}$ \\
\hline
\end{tabular}




\begin{tabular}{|l|l|l|}
\hline Creative Description & $\begin{array}{l}\text { AD that interprets the } \\
\text { audiovisual source text at a } \\
\text { connotative level to deliver } \\
\text { the global meaning of the } \\
\text { described fragment. }\end{array}$ & $\begin{array}{l}\text { Discursive Creation } \\
\text { "To establish a temporary equivalence that } \\
\text { is totally unpredictable out of context." }\end{array}$ \\
\hline Modulation & $\begin{array}{l}\text { A change of focus in the AD } \\
\text { compared to the original } \\
\text { audiovisual text. }\end{array}$ & $\begin{array}{l}\text { Modulation } \\
\text { "To change the point of view, focus or } \\
\text { cognitive category in relation to the ST." }\end{array}$ \\
\hline Variation & $\begin{array}{l}\text { A deviation of standard } \\
\text { language or neutral aural } \\
\text { delivery in the AD. }\end{array}$ & $\begin{array}{l}\text { Variation } \\
\text { "To change linguistic or paralinguistic } \\
\text { elements (intonation, gestures) that affect } \\
\text { aspects of linguistic variation: changes } \\
\text { of textual tone, style, social dialect, } \\
\text { geographical dialect, etc." }\end{array}$ \\
\hline
\end{tabular}

\section{A comparative analysis of the $\mathrm{AD}$ of cinematic language using ADTs}

AD techniques allow both a study of audio descriptive texts and a reflection over the decision-taking processes that take place in the describer's mind, which makes them an interesting analysis tool for $\mathrm{AD}$ research. To illustrate this, we will present the results of a comparative study of how audio describers approached cinematic language (i.e. camera work and editing) in three audio descriptions of Slumdog Millionaire (2008): the English, the German and the Spanish ADs. We have chosen this film because it has both a wide target audience and a creative direction, going well beyond mainstream cinematic conventions. We have identified film fragments involving particular expressions of cinematic language and analysed them following approaches based mainly on film semiotics (Casetti \& di Chio, 1991; Edgar-Hunt et al., 2010) and approaches from the more recent field of cognitive film studies (Plantinga, 2009; Bordwell \& Thompson, 2010). Subsequently, we have organised the film fragments in five categories that reflect the issues encountered:

- $\quad$ Passing of time;

- $\quad$ Places (as long as they are shown by a special filming or editing technique);

- Characters, which includes looks and thoughts expressed through editing techniques, and emotions (not all kind of emotion displays are taken into account, only those that rely on a special film technique);

- Creative cutaways. A cutaway is "a brief shot that momentarily interrupts a continuously-filmed action, by briefly inserting another related action, object, or person (sometimes not part of the principal scene or main action)" (Dirks, 1996). Creative cutaways allow the director to add information to supplement the narrative and to announce or recall elements that are part of the story - and they have been used profusely in Slumdog Millionaire; 
- Transitions, which are the articulation of the filmic narrative. They ensure the fluidity of the filmic discourse - or deliberately break its continuity. Besides, the transition between two juxtaposed shots may generate a meaning of its own, e.g. by showing a contrast of two scenes.

In total, we have compared ninety audio described fragments (thirty in each $\mathrm{AD}$ version). We have analysed each fragment from a filmic point of view, identified the ADT used by each describer and whether or not cinematic language had been rendered in the $\mathrm{AD}$. In this paper, we will present two detailed examples to illustrate how we have proceeded.

Our first example is a transition between a flashback and reality, where, during the Who Wants To Be A Millionaire game show, Jamal has been reminded of painful events of his childhood by the question he is to answer [TCR 00:21:50]. Here, it is the mise en cadre that conveys additional meaning: the camera focusses on Jamal's left ear and part of the back of his head on the right of the frame, while the greater left part is occupied by a blurry and slanted image of the host and audience. It is a "subjective" or "point of view shot" which does not try to give an objective image but to make us feel the way the character does (Casetti \& di Chio 1991, p. 250-251). So, we see things from Jamal's perspective, and what we see conveys a feeling that he is not fully there, that he has a hard time coming back to reality, obviously because of the disturbing memories that have resurfaced. The overlapping of the background music that starts at the end of the flashback intensifies this feeling.

The three describers took different approaches to describe the scene. The English AD reads:

[EN] "Present day. Jamal sits on the studio stage opposite the host."

This is an iconic description that treats the shot just like in any other scene change, informing us on the setting and characters of the following fragment (Ofcom, 2000, p.13) and does not interpret the meaning conveyed by how things are shown, thus leaving the emotional dimension of the shot untranslated. The German and Spanish descriptions, on the contrary, provide us with the following cognitive descriptions:

[DE] "Im Studio. Abwesend betrachtet Jamal die applaudierenden Zuschauer. Er löst sich aus seinen Gedanken." [In the TV studio. Jamal absently looks at the applauding audience. He comes back from his thoughts.]

[ES] "En el presente, en comisaría. Siguen viendo el vídeo del concurso. Jamal parece olvidar sus recuerdos y volver a la realidad." [Present day, at the police station. They are still watching the video of the show. Jamal seems to forget his memories and come back to reality.] 
These two ADs do include the emotional aspects of the shot. They are the result of an interpretation of the cinematic characteristics of the frame in its context. The aim of the interpretation is not to transmit the describer's opinion but to help the visually impaired audience grasp the meaning conveyed by how things are shown, which would be hard to achieve by describing the effects used (e.g. with a technical description or an integral iconic description) as this would break the rhythm and feeling of the original motion picture. In addition, the Spanish AD includes an amplification and a modulation (change of spatial focus), in the form of an explicitation, as it reminds us that we are at the police station watching the TV show although there is no shot of the situation at this moment.

Our second example is a creative cutaway which creates meaning through editing: it is an example of the "semantic function" of editing (Aumont et al., 1992, p.50). A thought is expressed through the insertion of a scene within another: Jamal meets his brother Salim up in a building in construction, years after the last time he had seen him, but still angry about what he had done [TCR 01:10:06]. Salim welcomes his little brother with open arms but, suddenly, Jamal runs at him, pushes him off the building and falls with him. After a series of shots showing us several seconds of fall into the void, a close-up on Jamal's blinking eyes makes us realize that nothing had happened: it was just a thought. The next shot is one of Jamal punching Salim in the face: we are back to reality.

The three approaches taken by describers to describe this scene illustrate the main ways to approach cinematic language in AD. First, the German AD is an iconic description that reads:

[DE] "Mit aller Kraft packt Jamal seinen Bruder und stößt ihn mit sich aus dem Hochhaus in die Tiefe. Im oberen Stockwerk. Jamal läuft zu Salim und schlägt ihn zu Boden." [With all his strength, Jamal takes his brother and pushes him so they both fall off the building. Upstairs. Jamal runs towards Salim and punches him to the ground.]

This is a description of what is shown at a denotative level, an iconic reading of the scene. Only the space marker "upstairs" is there to notify that we are back in the building. The audio describer does not interpret the meaning of cinematic language and the visually impaired audience has to process the information to deduce both the extent of Jamal's rage and the visual trick the director has played on viewers. The English $\mathrm{AD}$, on the contrary, is a cognitive description which starts with denotative elements but then gives a verbal cue to tie in the two parts of the scene:

[EN "Jamal lunges for Salim and they both fall off the building. Jamal blinks awake from his vision and punches Salim instead."

In this case, an interpretation of cinematic language, "blinks awake from his vision", ensures that it is made available to the visually impaired audience. Finally, 
the Spanish AD is a creative description which re-narrates the scene for blind and partially sighted spectators:

[ES] "Yamál explota de rabia. Querría lanzarlo al vacío y matarlo, pero no, se acerca y le encaja un buen derechazo en la mandíbula, que hace caer a Salím al suelo." [Jamal explodes in rage. He would like to throw him off the building and kill him, but, no, he comes near him and takes a swing at his jaw, which makes Salim fall to the ground.]

In this version, the describer interprets the connotative aspect of the scene - the intensity of Jamal's anger and resentment - but the visual impression of the fall into the void remains secondary.

The thorough analysis of the ninety AD fragments of Slumdog Millionaire using ADTs has allowed us to make the following observations:

- Looks, expressed by the shot/reverse shot technique, were always interpreted and translated into words (100\%).

- Thoughts, dreams and flashbacks were often interpreted (73\%), i.e. introduced by verbs, such as in "Jamal daydreams and remembers a young Latika standing on the tracks as their train pulls away."

- Other expressions of cinematic language were treated in various ways: the expression of the passing of time through cinematic means (see example 14) was included more often than not (67\%), whereas expressions related to places and creative cutaways were included only half of the time (respectively $53 \%$ and $56 \%)$.

- Emotions expressed by means of cinematic language were under-represented, with only one third being translated into words (33\%), and so were transitions (40\%).

Apart from these observations, we could establish that some $\mathrm{AD}$ techniques are more suitable than others to translate cinematic language into words. Of course, this does not mean that they are the only valid options to draft any AD script - but they should be remembered and taken into account when describing film fragments with a rich cinematic syntax. Figure 1 shows which ADT were used to approach cinematic language and if the meaning of cinematic techniques was translated into the $\mathrm{AD}$ or not. 
Figure 1 - Translation of cinematic language by ADT

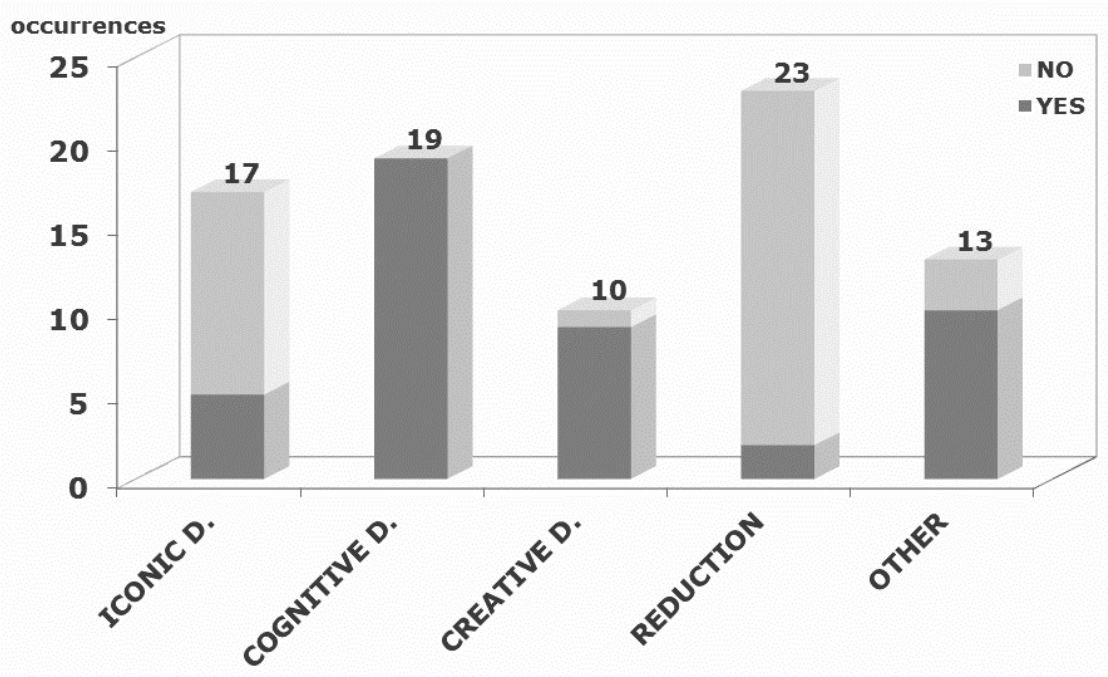

As we can see on Figure 1, cinematic language was relatively often ignored in the $\mathrm{AD}$ and we observe numerous reductions (omissions). The techniques that most often translated the meaning of cinematic language into the $\mathrm{AD}$ are cognitive description and creative description, which interpret the meaning of cinematic language, while iconic description, although it was often used, mostly did not translate the meaning of cinematic techniques into words. This result clashes with guidelines, which prescribe a denotative approach such as that of iconic description and state that audio describers should refrain from interpreting images (Dosch \& Benecke, 2004; Ofcom, 2000; AENOR, 2005; Morisset \& Gonant, 2008). Far from dismissing ADTs as an AD analysis tool, our observations concur with those by Kleege (2018, p.98), who is both a Disabilities scholar and an AD user, and observes that

while it is understandable that a certain level of consistency and professionalism is necessary, the rules and guidelines that have become codified seem to arise from problematic assumptions about what blind people can understand and should know about visual phenomena.

ADTs can help break these stereotypes by spotting potential issues, thus opening the way for solutions to be tested with blind and partially sighted audiences. In this sense, the results of the study presented in this paper are in line with user research in the field. For example, Walczak (2017) tested a "creative AD style", which includes cognitive and creative descriptions to render cinematic language into words, and Bardini (2020) tested the experience of blind and partially sighted users with a "cinematic AD style", where cognitive description is used predominantly and a "narrative AD style" with more creative descriptions, against a "conventional AD style" with mostly iconic descriptions. The results of these two projects converge towards the same observation: in spite of guidelines' 
instructions, the use of interpretative $\mathrm{AD}$ techniques is welcomed by end users and enhances their experience (Walczak, 2017, p. 390; Bardini, 2020, p. 17).

\section{Conclusion}

In this paper we have shown that $\mathrm{AD}$ is a form of intersemiotic translation and that research in the field can benefit from Translation Studies approaches. We have proposed an adaptation of Molina and Hurtado's (2002) taxonomy of translation techniques, which is based on a functional approach to the translation of texts. Merging earlier research on $\mathrm{AD}$ texts and Molina and Hurtado's classification, we have established a list of fourteen $\mathrm{AD}$ techniques (ADT) that can be used as analysis tools for descriptive studies of audio descriptions, as well as in the training of future audio describers, to approach $\mathrm{AD}$ issues from different angles and examine how describers' decisions affect the audio described film.

$\mathrm{AD}$ techniques work at a micro-level and can be used to analyse specific issues such as cultural references or cinematic language, but also emotions, humour, or gender issues, to name only a few. In this paper, we have presented a study on the $\mathrm{AD}$ of cinematic language using $\mathrm{ADT}$ and found that the approach to the translation of cinematic language into AD directly affects how cinematic language is made available (or not) to the blind and partially sighted audiences. This, in turn, may affect their experience, as several user studies have shown. In this sense, ADTs appear to be a useful tool to contrast audiovisual texts and their translation into words, $\mathrm{AD}$ requirements and $\mathrm{AD}$ practices, describers' decisions and users' reactions, to help improve guideline and practices and, ultimately, users' experience.

Acknowledgements: We want to thank Iñaki Arrubla (Navarra de Cine) for sharing his script of the Spanish AD of Slumdog Millionnaire, Deutsche Hörfilm gGmbH for letting us work with the German AD script, and Pathé UK for authorizing the use of the English AD script.

\section{Notes}

1. The UN Convention on the Rights of Persons with Disabilities came into force in May 2008 and legal dispositions have been taken in countries and regions to comply with the Convention. It is the case of the Lei Brasileira de Inclusão da Pessoa com Deficiência, the Brazilian law on the statute of persons with disabilities, passed in 2015, or the European Accessibility Act, adopted in 2019 to improve access legislation in EU countries.

2. This research has been carried out under the supervision of Dr Eva Espasa Borràs. Eva Espasa Borràs

3. Slumdog Millionaire tells the story of Jamal, a young Indian Muslim of a lower caste who reaches the 20-million-Rupee question of the TV show Who Wants To Be A Millionaire. He is accused of cheating and brought to the police station, where he explains how he managed to achieve this feat. There, he watches the video of the show with the inspector and tells him different episodes of his life, through which he learnt the answers to the questions in the game. This results in 
a complex narrative structure where past and present are constantly intertwined in a film that takes the audience on a singular trip to India.

4. TCR = Time Code Reading, is the time reference corresponding to each film fragment mentioned.

\section{References}

Adlab Pro (2016). Audio Description: A laboratory for the development of a new professional profile. https://adlabpro.wordpress.com [accessed 11/12/2019].

Aenor (2005). Norma UNE 153020:2005. Audiodescripción para personas con discapacidad visual. Requisitos para la audiodescripción y elaboración de audioguías. Madrid: AENOR.

Aumont, J., Bergala, A., Marie, M. and Vernet, M. (1992). Aesthetics of Film. Translated by R. Neupert. Austin: University of Texas Press.

Bardini, F. (2020). Film language, film emotions and the experience of blind and partially sighted viewers: a reception study. JoSTrans: The Journal of Specialized Translation, (33).

Bordwell, D. and Thompson, K. (2010). Film Art: An Introduction, $9^{\text {th }}$ Edition. New York: McGraw-Hill.

Braun, S. (2008). Audio description research: state of the art and beyond. Translation Studies in the New Millenium, (6), p.14-30.

Cámara, L. and Espasa, E. (2011). The audio description of scientific multimedia. The Translator, 17(2), p. 415-437.

Casetti, F. and di Chio, F. (1991). Cómo Analizar Un Film. Translated by C. Losilla. Barcelona: Paídos.

Díaz Cintas, J. (2005). Audiovisual translation today. A question of accessibility for all. Translation Today, (4), p. 3-5.

Díaz Cintas, J. (2007a). Traducción audiovisual y accesibilidad. In C. Jímenez Hurtado (Ed.) (2007), Traducción y Accesibilidad, p. 9-23. Bern: Peter Lang.

Díaz Cintas, J. (2007b). Por una preparación de calidad en accesibilidad audiovisual. Trans. Revista de Traductología, (11), p. 45-59.

Dirks, T. (1996). Film term glossary illustrated. http://www.filmsite.org/filmterms. html [accessed 11/12/2019].

Dosch, E. and Benecke, B. (2004). Wenn Aus Bildern Worte Werden. Durch AudioDescription Zum Hörfilm, $3^{\text {rd }}$ Edition. Munich: Bayrischer Rundfunk.

Edgar-Hunt, R., Marland, J. and Rawle, S. (2010). The Language of Film. Basics FilmMaking 04. Lausanne: AKA Publishing.

Fryer, L. (2016). An Introduction to Audio description: A Practical Guide. London: Routledge.

Fryer, L. and Freeman, J. (2013). Cinematic language and the description of film: keeping AD users in the frame. Perspectives: Studies in Translatology, 21(3), p. $412-426$.

Fryer, L. and Romero-Fresco, P. (2014). Audio introductions. In A. Maszerowska, A. Matamala and P. Orero (Eds.) (2014), Audio Description: New perspectives illustrated, p. 9-28. Amsterdam: John Benjamins.

Gil Bardají, A. (2009). Procedures, Techniques, Strategies: Translation Process Operators. Perspectives: Studies in Translatology, 17 (3), p. 161-173. 
González Davies, M. (2004). Multiple Voices in the Translation Classroom. Amsterdam: John Benjamins.

González Davies, M. and Scott-Tennent, C. (2005). A problem-solving and studentcentered approach to the translation of cultural references. Meta : journal des traducteurs / Meta: Translators' Journal, 50 (1), p. 160-179.

Igareda, P. (2011). The audio description of emotions and gestures in spanish-spoken films. In A. Şerban, A. Matamala and J.-M. Lavaur (Eds.) (2011), Audiovisual Translation in Close-Up: Practical and Theoretical Approaches, p. 223-238. Bern: Peter Lang.

Jakobson, R. (1959). On linguistic aspects of translation. In L.Venuti (Ed.) (2000), The Translation Studies Reader, p. 113-118. London: Routledge.

Kleege, G. (2018). More than meets the eye. New York: Oxford University Press.

Martí Ferriol, J.-L. (2006). [Doctoral thesis]. Estudio empírico y descriptivo del método de traducción para doblaje y substitulación. Castelló de la Plana: Universitat Jaume I.

Matamala, A. and Rami, N. (2009). Análisis comparativo de la audiodescripción española y alemana de 'Goodbye Lenin'. Hermēneus. Revista de traducción e interpretación, (11), p. 249-266.

Mazur, I. (2014). Gestures and facial expressions in audio description. In A. Maszerowska, A. Matamala and P. Orero (Eds.) (2014), Audio Description: New perspectives illustrated, p. 179-198. Amsterdam: John Benjamins.

Mazur, I. (2015). Characters and actions. In A. Remael, G. Vercauteren and N. Reviers (Eds.) (2015), Pictures painted in words. The ADLAB audio description guidelines. http://www.adlabproject.eu/Docs/adlab\%20book/index.html [accessed 11/12/19].

Metz, C. (1959). Le cinéma : langue ou langage ? Communications, (4) (1964), p. $52-90$.

Molina, L. and Hurtado A. (2002). Translation techniques revisited: a dynamic and functionalist approach. Meta : journal des traducteurs / Meta: Translators' Journal, $47(4)$, p. $498-512$.

Morisset, L. and Gonant, F. (2008). La Charte de l'audiodescription. https://www. sdicine.fr/wp-content/uploads/2015/05/Charte-de-laudio-description-1008.pdf [accessed 11/12/2019].

Muñoz, R. (2000). Translation techniques over the rainbow. In A. Beeby, D. Ensinger and M. Presas (Eds.) (2000), Investigating Translation. Selected Papers from the $4^{\text {th }}$ International Congress on Translation, Barcelona, 1998, p. 129-137. Amsterdam: John Benjamins.

Ofcom (2000). ITC Guidance on Standards for Audio Description. London: Ofcom.

Orero, P. (2008). Three different receptions of the same film. European Journal of English Studies, 12(2), p. 179-193.

PACTE (2011). Results of the validation of the PACTE's translation competence model: translation problems and translation competence. In C. Alvstad, A. Hild and E. Tiselius (Eds.) (2011), Methods and Strategies of Process Research: Integrative Approach in Translation Studies, p. 317-343. Amsterdam: John Benjamins.

Pedersen, J. (2011). Subtitling Norms on Television: An Exploration Focussing on Extralinguistic Cultural References. Amsterdam: John Benjamins.

Perego, E. (2015). Film language. In A. Remael, G. Vercauteren and N. Reviers (Eds.) (2015), Pictures Painted in Words. The ADLAB Audio Description Guidelines. http:// www.adlabproject.eu/Docs/adlab\%20book/index.html [accessed 11/12/2019]. 
Plantinga, C. (2009). Moving Viewers. Berkeley: University of California Press.

Pym, A. (2003). Redefining Translation Competence in an Electronic Age. In Defence of a Minimalist Approach. Meta : journal des traducteurs / Meta: Translators' Journal, 48(4), p. 481-497.

Reiss, K. (1981). Type, kind and individuality of text: decision making in translation. Poetics Today, 2(4), p. 121-131.

Sanz-Moreno, R. (2017). La (auto)censura en audiodescripción: El sexo silenciado. Parallèles, 29(2), p. 46-63.

Sanz-Moreno, R. (2018). El uso de extranjerismos en audiodescripción: La opinión de los usuarios. Parallèles, 30(2), p. 53-69.

Slumdog Millionaire (2008). [Motion picture]. Directed by D. Boyle and L. Tandan. Pathé UK [DVD].

Szarkowska, A. (2013). Auteur description: from the director's creative vision to audio description. Journal of Visual Impairment \& Blindness, September - October 2013, p. 383-387.

Szarkowska, A. and Jankowska, A. (2015). Audio describing foreign films. JoSTrans: The Journal of Specialised Translation, (23), p. 243-269. http://www.jostrans.org/ issue23/art_szarkowska.php [accessed 11/12/2019].

Utray, F., Pereira, A.-M. and Orero, P. (2009). The present and future of audio description and subtitling for the deaf and the hard of hearing in Spain. Meta : journal des traducteurs / Meta: Translators' Journal, 54 (2), p. 248-263.

Vinay, J.-P. and Darbelnet, J. (1958). Stylistique comparée du français et de l'anglais. Méthode de traduction. Paris: Didier.

Walczak, A. and Figiel, W. (2013). Domesticate or foreignize? Culture-specific items in audio description. Paper read at the $2^{\text {nd }}$ Intermedia conference, Łódź, $22^{\text {nd }}-23^{\text {rd }}$ November 2013.

Walczak, A. (2017). Creative description: The impact of audio description style on presence in visually impaired audiences. British Journal of Visual Impairment, 35(1), p. 6-17.

Zabalbeascoa, P. (2000). From techniques to type of solutions. In A. Beeby, D. Ensinger and M. Presas (Eds.) (2000), Investigating Translation. Selected Papers from the $4^{\text {th }}$ International Congress on Translation, Barcelona, 1998, p. 117-127. Amsterdam: John Benjamins.

Zabalbeascoa, P. (2008). The nature of the audiovisual text and its parameters. In J. Díaz Cintas (Ed.) (2008), The Didactics of Audiovisual Translation, p. 21-37. Amsterdam: John Benjamins. 